

\title{
Quality of semen of young boars of the breeds Pietrain and Duroc and their reciprocal crosses
}

\begin{abstract}
The study concerned examination of 120 of young Pietrain and Duroc boars and hybrids descending from reciprocal crossing of those breeds. On $230^{\text {th }}, 250^{\text {th }}$ and $270^{\text {th }}$ day of their lives, their sperm was given a detailed examination. It is assessed that Pietrain boars gave ejaculates of the lowest volume, lowest mobility, and the lowest total number of spermatozoa. Semen of boars of this group had also the highest percentage of spermatozoa with major and minor morphological changes, and defected acrosome. Along with the age of boars (from $230^{\text {th }}$ to $270^{\text {th }}$ day of life) there was a significant improvement of quality of semen of all of the groups except the semen of Pietrain boars.

We detected the positive effect of crossing especially in hybrids boars descending from mating of Duroc fathers and Pietrain mothers. Even during the first evaluation, they gave the semen of the highest total number of normal sperms, with normal acrosome, and with the highest value of osmotic resistance test and the lowest activity of AspAT in semen plasma. That proves the high quality of ejaculates of those hybrids comparing to the ejaculates of the boars of other groups - purebreds as well as hybrids of the opposite combination, i.e. descending from crossing of Pietrain fathers and Duroc mothers. This conclusion suggests to use Duroc fathers and Pietrain mothers in production of hybrid boars.
\end{abstract}

Key Words: Pietrain, Duroc, reciprocal crossing, boars, semen quality, defects of spermatozoa

\section{Zusammenfassung}

Titel der Arbeit: Spermaqualität junger Pietrain- und Duroceber sowie Ebern aus deren reziproken Kreuzungen

Am 230., 250. und 270. Lebenstag wurde das Sperma von je 30 Ebern der Rassen Pietrain, Duroc sowie deren reziproken Kreuzungen untersucht. Pietraineber hatten das geringste Ejakulatvolumen, die geringste Zahl beweglicher Spermien und Gesamtspermienzahlen. Ebenso fanden sich bei diesen Tieren der größte Anteil kleinerer und größerer morphologischer Veränderungen und Akrosomendefekte. Mit Ausnahme der Pietraineber verbesserte sich die Spermaqualität mit zunehmendem Alter der Eber. Besonders positive Effekte fanden sich bei den Kreuzungsebern aus Durocvätern. Sie zeichneten sich bereits beim frühesten Untersuchungstermin durch hohe Spermaqualität, höchste Testwerte der osmotischen Resistenz und geringste Aktivität des AspAt-Enzyms aus. Damit unterschieden sie sich signifikant sowohl von den Reinzuchtgruppen als auch den Kreuzungen aus Pietrainvätern. Es wird geschlussfolgert, das aus der Sicht der Spermaqualität die Kreuzungseber aus Durocvätern mit Pietrainmüttern am vorteilhaftesten sind.

Schlüsselwörter: Pietrain, Duroc, reziproke Kreuzung, Eber, Spermaqualität, Spermiendefekte

\section{Introduction}

Cross breeding of swine is a method in which we can improve the efficiency of production, especially through the disclosure of the effects of heterosy seen in features of reproduction. Therefore many countries, including Poland, have been using not only hybrid sows but also hybrid boars for reproduction for many years. Many studies have proved that they are characterized by a better libido, larger testis size, better quality of semen and a higher conception rate percentage than in purebred boars (WILSON et al., 
1977; NELLY et al., 1980; FENT et al., 1983; NELLY and ROBISON, 1983). The current recommended crossing of pig breeds has two stages, and uses four breeds two mother breeds and two father breeds. In many countries the main representatives on the father's side are Pietrain and Duroc boars. This usually creates the desired production effects through the crossing of these individual breeds, for example: the gaining of meat free from quality defects and a better quality and quantity semen characteristics. The quality of semen is extremely important while using hybrid boars for insemination, where the amount of insemination doses are very important, as well as fertilization of the highest possible number of ovulating egg cells, which depends on the good quality of the semen (STRZEŻEK, 1998). However, it is worth emphasizing that although the crossing of different breeds of swine is a commonly accepted form of mating, it is very important to choose suitable breeds or lines to cross. The position of particular breed being mother or father of a hybrid boar is also very significant. It is important because the tendency towards higher production may be accomplished by the descendants of better "fitting" parent genotypes. Also there may be the appearance of the mother's influence on a particular feature.

For many years we have been observing a decrease in the reproductive performance of boars. Many studies proved, that this could be the result of a unilateral selection for the increase in leanness (FALKENBERG et al., 1989; KAWECCKA et al., 1997; DZIADEK, 1999). The entire reproduction process is the basis for the maximal utilization of the performance traits of pigs. Therefore, except for the evaluation of the libido, a full examination of semen, especially in young boars starting at their period of reproduction ability and taking the morphological changes of spermatozoa (and their forms) into consideration is very significant. Morphological examination of spermatozoa allows the most objective evaluation of semen. Type and number of morphological defects of spermatozoa shows the level of irregularity of spermatogenesis (MORSTIN, 1996). It is possible to gain quite varied quality and quantity traits of semen from different breeds and their hybrids.

The aim of this study was the evaluation of semen of young, purebred Pietrain and Duroc boars and crossbreds resulting from the reciprocal crossing of those breeds, with special consideration of the morphology of spermatozoa. Additionally, the phenotypic correlation coefficient between the morphological defects of spermatozoa and other traits of semen was also assessed.

\section{Material and Methods}

The studies were conducted in the Experimental, Zootechnic Plant of Pawłowice, which is a property of the Institute of Animal Production of Kraków. The material under investigation consisted of 120 young boars, resulting from the mating of:

1 group - Duroc breed (DxD) - 30 heads,

2 group - Pietrain breed (PxP) - 30 heads,

3 group - $\overbrace{}^{\lambda} \mathrm{Px}+\mathrm{D}-30$ heads,

4 group - $\overbrace{}^{\lambda} \mathrm{Dx}+\mathrm{P}-30$ heads.

In each of the groups the boars originated from 30 mothers and 6 fathers and were kept in the same environmental conditions. Until the $35^{\text {th }}$ day of life the piglets were kept with their mothers, and after separation the sows stayed in farrowing pens until the $70^{\text {th }}$ day of life. During that time they were fed with prestarter and grower mixtures, according to Polish norms of feeding. After routine selection of boars, they were 
transferred to individual pens without straw, being $1 \times 2 \mathrm{~m}$ in dimension with hard and slatted flooring (respectively 60:40), where they stayed until the end of the evaluation. In the period from the $71^{\text {st }}$ day of life until the end of examination, the animals were fed, depending on age, with full ratio mixture having nutritive value of: $1 \mathrm{~kg}$ of mixture: 13 MJEM, $187 \mathrm{~g}$ of crude protein, 10,5 g of lysine, 6,7 $\mathrm{g}$ of methionine with cystine.

After teaching the boars to mount a phantom, their semen was evaluated in the $230^{\text {th }}$, $250^{\text {th }}$ and $270^{\text {th }}$ day of their life. Ejaculate volume, percentage of spermatozoa with normal motile, concentration of spermatozoa (Bürker's chamber), total number of spermatozoa was tests were made.

According to BLOM's classification (1981) the defects were divided into major and minor defects, evaluating the frequency of appearance of particular forms of morphologically changed spermatozoa. The percentage of spermatozoa with normal acrosome was assessed according to SAACKE and WHITE (1972). Within the semen plasma of the examined boars we evaluated the activity of asparagine aminotransferaze (AspAT) with the use of a kinetic method, and later the level of that enzyme was counted within $1 \times 10^{9}$ of spermatozoa.

During the evaluation of semen in the $230^{\text {th }}$ and $270^{\text {th }}$ day of the boars' life, we carried out an osmotic resistance test of acrosomal membranes of spermatozoa (ORT), according to SCHILING and VENGUST (1987). The results went under statistic analysis, with the use of the Statistica PL programme. The linear model included the influence of genetic groups and the influence of the sire. We used the analysis of variance to assess the significant differences between the traits of semen and we assessed the phenotypic correlation coefficient.

\section{Results}

The data presented in Table 1 shows, that, along with the age of boars (during the following examinations in the $230^{\text {th }}, 250^{\text {th }}$ and $270^{\text {th }}$ day of life) the volume of ejaculate increases, and so does the concentration of spermatozoa and total number of spermatozoa in the entire ejaculate. The increase in the volume of ejaculate was connected to age, took place in all of the boars, except Pietrain boars. Pietrain boars also gave semen with the lowest mobility of spermatozoa during the next evaluation. The differences were statistically significant $(\mathrm{P} \leq 0.05$ and $\mathrm{P} \leq 0.01)$.

Among all of the groups, Duroc boars gave the semen with the highest concentration of spermatozoa in the following ejaculates, and the semen with the lowest concentration was found in the hybrid boars descended from the crossing of Pietrain fathers and Duroc mothers $(\mathrm{P} \leq 0.05$ and $\mathrm{P} \leq 0.01)$. It is worth mentioning, that the semen of hybrid boars of an opposite combination (Duroc fathers and Pietrain mothers) had a semen concentration similar to Duroc boars. With aging the reproducers concentration of spermatozoa also increased. The differences detected during the first evaluation of semen were constant also during the following test.

The total number of spermatozoa in ejaculate is a resultant of volume of semen and concentration of spermatozoa. During the first evaluation of ejaculates, the semen of Duroc boars had the highest total number of spermatozoa and hybrid boars descending from crossing of Duroc fathers and Pietrain mothers, and the hybrid boars of the opposite combination had the lowest (gr. 3) as well as Pietrain boars. The differences between the semen of Duroc boars and hybrid boars of gr. $3\left({ }^{\lambda} \mathrm{Px}+\mathrm{D}\right)$ had a statistical 
significance at $\mathrm{P} \leq 0.05$. Along with the age of boars, the total number of spermatozoa increased, especially in ejaculates of Duroc boars (by $16,5 \times 10^{9}$ of spermatozoa). The evaluation carried out on the $270^{\text {th }}$ day of life showed statistically significant differences $(\mathrm{P} \leq 0.01)$ between Duroc boars and boars of different groups. The lowest total number of spermatozoa in the three evaluated periods had Pietrain boars and hybrid boars of gr. $3(\overbrace{}^{\Uparrow} \mathrm{Px}+\mathrm{D})$.

Table 1

Mean values of traits semen of purebred young boars Pietrain, Duroc and their crossbreds (Durchschnittliche Ejakulatparameter bei Pietrain- und Durocebern sowie ihren Kreuzungen)

\begin{tabular}{|c|c|c|c|c|c|c|}
\hline \multirow{2}{*}{ Traits } & \multirow{2}{*}{$\begin{array}{l}\text { Time of } \\
\text { evaluation }\end{array}$} & \multicolumn{5}{|c|}{ Group } \\
\hline & & $\begin{array}{c}1 \\
\mathrm{DxD}\end{array}$ & $\begin{array}{c}2 \\
\mathrm{PxP} \\
\end{array}$ & $\begin{array}{c}3 \\
\delta^{\top} \mathrm{Px}+\mathrm{D}\end{array}$ & $\begin{array}{c}4 \\
\sigma^{\top} \mathrm{Dx}+\mathrm{P}\end{array}$ & SEM \\
\hline Ejaculate volume, $\mathrm{cm}^{3}$ & $\begin{array}{c}\text { I } \\
\text { II } \\
\text { III }\end{array}$ & $\begin{array}{l}139.6 \\
162.7^{\mathrm{a}} \\
180.0^{\mathrm{a}}\end{array}$ & $\begin{array}{l}139.7 \\
147.1^{\text {В }} \\
145.5^{\text {Аа }}\end{array}$ & $\begin{array}{l}160.3^{\mathrm{a}} \\
195.5^{\mathrm{ABa}} \\
203.0^{\mathrm{AB}}\end{array}$ & $\begin{array}{l}135.3^{\mathrm{a}} \\
155.0^{\mathrm{A}} \\
161.7^{\mathrm{B}}\end{array}$ & $\begin{array}{l}4.08 \\
5.52 \\
5.99\end{array}$ \\
\hline Motile spermatozoa, \% & $\begin{array}{c}\text { I } \\
\text { II } \\
\text { III }\end{array}$ & $\begin{array}{l}75.2^{\mathrm{bc}} \\
75.8^{\mathrm{a}} \\
76.5^{\mathrm{BC}}\end{array}$ & $\begin{array}{l}70.3^{\mathrm{Ab}} \\
71.6^{\mathrm{Aa}} \\
71.9^{\mathrm{AB}}\end{array}$ & $\begin{array}{l}71.5^{\text {ac }} \\
73.5^{\text {AC }} \\
72.5^{\text {AC }}\end{array}$ & $\begin{array}{l}76.0^{\text {Aa }} \\
77.0^{\mathrm{A}} \\
77.7^{\mathrm{A}}\end{array}$ & $\begin{array}{l}0.68 \\
0.62 \\
0.60\end{array}$ \\
\hline $\begin{array}{l}\text { Concentration of } \\
\text { spermatozoa, } \\
\mathrm{n} \times 10^{6} / \mathrm{cm}^{3}\end{array}$ & $\begin{array}{l}\text { I } \\
\text { II } \\
\text { III }\end{array}$ & $\begin{array}{l}189.1^{\mathrm{A}} \\
210.4^{\mathrm{Aa}} \\
229.4^{\mathrm{A}}\end{array}$ & $\begin{array}{l}158.6 \\
169.2^{\mathrm{a}} \\
194.1^{\mathrm{a}}\end{array}$ & $\begin{array}{l}123.9^{\mathrm{AB}} \\
137.0^{\mathrm{AB}} \\
149.9^{\mathrm{ABa}}\end{array}$ & $\begin{array}{l}191.2^{\mathrm{B}} \\
198.8^{\mathrm{B}} \\
215.4^{\mathrm{B}}\end{array}$ & $\begin{array}{l}8.16 \\
7.12 \\
7.53\end{array}$ \\
\hline $\begin{array}{l}\text { Total number of } \\
\text { spermatozoa, } \mathrm{n} \times 10^{9}\end{array}$ & $\begin{array}{l}\text { I } \\
\text { II } \\
\text { III }\end{array}$ & $\begin{array}{l}21.5^{\mathrm{a}} \\
28.2^{\mathrm{Aa}} \\
38.0^{\mathrm{ABC}}\end{array}$ & $\begin{array}{l}17.7^{\mathrm{A}} \\
21.5^{\mathrm{A}} \\
24.8^{\mathrm{A}}\end{array}$ & $\begin{array}{l}16.7^{\mathrm{a}} \\
21.9^{\mathrm{a}} \\
26.3^{\mathrm{B}}\end{array}$ & $\begin{array}{l}20.6 \\
25.5 \\
28.4^{\mathrm{C}}\end{array}$ & $\begin{array}{l}0.86 \\
0.95 \\
1.25\end{array}$ \\
\hline $\begin{array}{l}\text { Spermatozoa with major } \\
\text { defects, \% }\end{array}$ & $\begin{array}{l}\text { I } \\
\text { II } \\
\text { III }\end{array}$ & $\begin{array}{l}10.33^{\mathrm{a}} \\
5.19^{\mathrm{A}} \\
4.46^{\mathrm{A}}\end{array}$ & $\begin{array}{l}10.92^{\mathrm{b}} \\
11.74^{\mathrm{ABC}} \\
12.19^{\mathrm{ABC}}\end{array}$ & $\begin{array}{l}9.33^{\mathrm{C}} \\
4.59^{\mathrm{B}} \\
4.73^{\mathrm{B}}\end{array}$ & $\begin{array}{l}3.17^{\mathrm{abc}} \\
3.50^{\mathrm{C}} \\
3.85^{\mathrm{C}}\end{array}$ & $\begin{array}{c}1.11 \\
0.9 \\
0.82\end{array}$ \\
\hline $\begin{array}{l}\text { Spermatozoa with minor } \\
\text { defects, \% }\end{array}$ & $\begin{array}{l}\text { I } \\
\text { II } \\
\text { III }\end{array}$ & $\begin{array}{l}7.17 \\
5.75^{\mathrm{a}} \\
5.19^{\mathrm{A}}\end{array}$ & $\begin{array}{l}9.42^{\mathrm{A}} \\
9.29^{\mathrm{Aab}} \\
10.71^{\mathrm{ABC}}\end{array}$ & $\begin{array}{l}7.23 \\
5.36^{\mathrm{b}} \\
5.45^{\mathrm{B}}\end{array}$ & $\begin{array}{l}4.58^{\mathrm{A}} \\
4.50^{\mathrm{A}} \\
5.10^{\mathrm{C}}\end{array}$ & $\begin{array}{l}0.57 \\
0.58 \\
0.59\end{array}$ \\
\hline Normal spermatozoa, \% & $\begin{array}{l}\text { I } \\
\text { II } \\
\text { III }\end{array}$ & $\begin{array}{l}82.50^{\mathrm{a}} \\
89.17^{\mathrm{A}} \\
89.96^{\mathrm{A}}\end{array}$ & $\begin{array}{l}80.13^{\mathrm{A}} \\
78.94^{\mathrm{ABC}} \\
77.13^{\mathrm{ABC}}\end{array}$ & $\begin{array}{l}83.45^{\mathrm{b}} \\
90.05^{\mathrm{B}} \\
89.83^{\text {В }}\end{array}$ & $\begin{array}{l}92.25^{\text {Aab }} \\
92.00^{\mathrm{C}} \\
91.10^{\mathrm{C}}\end{array}$ & $\begin{array}{l}1.45 \\
1.26 \\
1.12\end{array}$ \\
\hline $\begin{array}{l}\text { Spermatozoa with normal } \\
\text { acrosome, \% }\end{array}$ & $\begin{array}{l}\text { I } \\
\text { II } \\
\text { III }\end{array}$ & $\begin{array}{l}69.90^{\mathrm{a}} \\
70.06^{\mathrm{a}} \\
72.56^{\mathrm{A}}\end{array}$ & $\begin{array}{l}70.23^{\mathrm{b}} \\
69.57^{\mathrm{b}} \\
69.13^{\mathrm{ABC}}\end{array}$ & $\begin{array}{l}68.82^{\mathrm{A}} \\
69.90^{\mathrm{C}} \\
73.21^{\mathrm{B}}\end{array}$ & $\begin{array}{l}73.52^{\text {Aab }} \\
72.43^{\mathrm{abc}} \\
74.82^{\mathrm{C}}\end{array}$ & $\begin{array}{l}0.50 \\
0.49 \\
0.52\end{array}$ \\
\hline $\begin{array}{l}\text { Osmotic resistance test- } \\
\text { ORT, \% }\end{array}$ & $\begin{array}{l}\text { I } \\
\text { II } \\
\text { III }\end{array}$ & $\begin{array}{c}60.39^{\mathrm{a}} \\
- \\
59.03^{\mathrm{A}}\end{array}$ & $\begin{array}{c}62.28 \\
- \\
60.18^{\mathrm{B}}\end{array}$ & $\begin{array}{c}61.15^{\mathrm{b}} \\
- \\
62.51^{\mathrm{c}}\end{array}$ & $\begin{array}{l}64.94^{\mathrm{ab}} \\
- \\
66.53^{\mathrm{ABC}}\end{array}$ & $\begin{array}{r}0.63 \\
- \\
0.68\end{array}$ \\
\hline $\begin{array}{l}\text { AspAT in the semen } \\
\text { plasma, } U / 10^{9} \\
\text { spermatozoa } \mu \mathrm{g} / \mathrm{mL}\end{array}$ & $\begin{array}{l}\text { I } \\
\text { II } \\
\text { III }\end{array}$ & $\begin{array}{l}94.03 \\
82.90^{\mathrm{A}} \\
63.80^{\mathrm{A}}\end{array}$ & $\begin{array}{l}63.45 \\
73.73^{\mathrm{B}} \\
71.17^{\mathrm{B}}\end{array}$ & $\begin{array}{l}84.59 \\
71.80 \\
71.53^{\mathrm{C}}\end{array}$ & $\begin{array}{l}58.14 \\
50.57 \\
35.75\end{array}$ & $\begin{array}{l}6.33 \\
7.12 \\
4.42\end{array}$ \\
\hline
\end{tabular}

Table 1 shows also the results concerning morphological changes of spermatozoa, morphology of acrosome, ORT test and activity of AspAT in semen plasma. During the first evaluation, the highest percentage of spermatozoa with major defects was detected in semen of Pietrain boars and Duroc boars and hybrid boars resulting from 
the mating of Pietrain fathers and Duroc mothers. The lowest percentage of major defects in semen was found in the hybrid boars descending from the opposite crossing $\left({ }^{\lambda} \mathrm{Dx} \odot \mathrm{P}\right)$. The differences between this group and the others had a statistic significance $(\mathrm{P} \leq 0.05)$. Along with age, there was a clear decrease in the percentage of spermatozoa with major defects in the semen of the examined groups, except the semen of Pietrain boar group. The differences between this group of boars and the others were statistically significant $(\mathrm{P} \leq 0.01)$.

The data of Table 1 shows, that similarly to major defects of spermatozoa, the lowest percentage of minor in semen defects was seen in the hybrid boars descending from the crossing of Duroc fathers and Pietrain mothers in the three evaluation periods. The highest percentage of those changes was found in the semen of Pietrain boars, similarly to the major defects. Those differences were statistically significant $(\mathrm{P} \leq 0.01$ and $\mathrm{P} \leq 0.05$ ).

The analysis of spermatozoa with normal acrosome showed that the highest percentage of such spermatozoa was in the semen of hybrid boars descending from crossing of Duroc fathers and Pietrain mothers. The differences, comparing to the other groups, were statistically significant $(\mathrm{P} \leq 0.01$ and $\mathrm{P} \leq 0.05)$. Along with next evaluations, the higher percentage of spermatozoa with normal acrosome in all of the groups except the Pietrain boars was observed. During the third evaluation, semen of this group of boars had the lowest number of spermatozoa with normal acrosome comparing to the other boars groups. This result was statistically significant $(\mathrm{P} \leq 0.01$ and $\mathrm{P} \leq 0.05)$. The results of acrosome morphology are analogic to results concerning major and minor defects of spermatozoa. The semen of Pietrain boars had the lowest number of normal spermatozoa, and this number did not increase along with the age (from the $230^{\text {th }}$ to $270^{\text {th }}$ day of life), as in reproducers of other groups (especially, where the percentage of major defects of spermatozoa decreased).

The highest values ORT test (statistically significant at $\mathrm{P} \leq 0.01$ and $\mathrm{P} \leq 0.05$ ) were detected in semen of hybrid boars descending from crossing of Duroc fathers and Pietrain mothers, during the first and the last evaluation.

Analysis of the activity of AspAT in semen plasma showed the lowest values of this parameter in the following ejaculates of hybrid boars descending from crossing of Duroc fathers and Pietrain mothers. Those results confirm the results discussed above. Ejaculates of boars from Duroc fathers and Pietrain mothers (gr. 4) had better parameters of semen quality (even during the first evaluation), than ejaculates of other groups of reproducers (purebreds and crossbreds of different combination). This concerns the major and minor defects of spermatozoa, spermatozoa with normal acrosome, osmotic resistance test of acrosomal membranes and AspAT activity.

Table 2 shows the forms of morphologically changed spermatozoa. The analysis of major defects detected, that the highest percentage of defected spermatozoa of semen of young boars are the spermatozoa with protoplasmatic proximal droplet (especially during the first evaluation). The highest percentage of spermatozoa with proximal droplet was detected in semen of Pietrain boars. The following evaluations showed the similar ranges of those changes. They were significantly higher $(\mathrm{P} \leq 0.01$ and $\mathrm{P} \leq 0.05)$ than the defects of semen of boars of other groups, especially during the second and third evaluation. Other forms of defected spermatozoa appeared in the semen of examined groups with different frequency, without connection to the time of evaluation. The results clearly show, that other forms of defected spermatozoa 
appeared mostly less than $1 \%$, in the following ejaculates. The clear decrease of number of this form of spermatozoa with the following evaluations of semen was not observed, as seen in the spermatozoa with protoplasmatic proximal droplet - their number decreased significantly.

Table 2

Characteristics spermatozoa with major and minor morphological defects (BLOM, 1981) (Art und prozentuale Häufigkeit von primären und sekundären Spermienanomalien bei Pietrain- und Durocebern sowie ihre Kreuzungen)

\begin{tabular}{|c|c|c|c|c|c|c|}
\hline & \multirow{2}{*}{$\begin{array}{c}\text { Time of } \\
\text { evaluation }\end{array}$} & \multicolumn{5}{|c|}{ Group } \\
\hline & & $\begin{array}{c}1 \\
\text { DxD } \\
\end{array}$ & $\begin{array}{c}2 \\
\text { PxP } \\
\end{array}$ & $\begin{array}{c}3 \\
{ }^{\Uparrow} \mathrm{Px}_{+} \mathrm{D} \\
\end{array}$ & $\begin{array}{c}4 \\
\delta^{\lambda} \mathrm{Dx}+\mathrm{P} \\
\end{array}$ & SEM \\
\hline \multicolumn{7}{|c|}{ Major defects, \% } \\
\hline Double forms & $\begin{array}{c}\text { I } \\
\text { II } \\
\text { III }\end{array}$ & $\begin{array}{l}0.17 \\
0.23^{\text {a }} \\
0.17\end{array}$ & $\begin{array}{l}0.01^{\mathrm{A}} \\
0.01^{\mathrm{ab}} \\
0.10^{\text {a }}\end{array}$ & $\begin{array}{l}0.30^{\mathrm{AB}} \\
0.21^{\mathrm{b}} \\
0.08\end{array}$ & $\begin{array}{l}0.01^{\text {B }} \\
0.14 \\
0.07\end{array}$ & $\begin{array}{l}0.04 \\
0.03 \\
0.03\end{array}$ \\
\hline Pear shaped head & $\begin{array}{c}\text { I } \\
\text { II } \\
\text { III }\end{array}$ & $\begin{array}{l}0.56^{\text {a }} \\
0.21 \\
0.12\end{array}$ & $\begin{array}{l}0.38 \\
0.26 \\
0.24\end{array}$ & $\begin{array}{l}0.35 \\
0.31 \\
0.14\end{array}$ & $\begin{array}{l}0.07^{\mathrm{a}} \\
0.10 \\
0.10\end{array}$ & $\begin{array}{l}0.07 \\
0.06 \\
0.05\end{array}$ \\
\hline Narrow at the base & $\begin{array}{c}\text { I } \\
\text { II } \\
\text { III }\end{array}$ & $\begin{array}{l}0.43^{\mathrm{a}} \\
0.50^{\mathrm{b}} \\
0.17^{\mathrm{A}}\end{array}$ & $\begin{array}{l}0.82^{\mathrm{abc}} \\
0.58^{\mathrm{a}} \\
0.81^{\mathrm{AB}}\end{array}$ & $\begin{array}{l}0.23^{b} \\
0.34 \\
0.44\end{array}$ & $\begin{array}{l}0.17^{\mathrm{c}} \\
0.15^{\mathrm{ab}} \\
0.17^{\mathrm{B}}\end{array}$ & $\begin{array}{l}0.09 \\
0.07 \\
0.09\end{array}$ \\
\hline Small abnormal head & $\begin{array}{c}\text { I } \\
\text { II } \\
\text { III }\end{array}$ & $\begin{array}{l}0.06 \\
0.06 \\
0.04\end{array}$ & $\begin{array}{l}0.10 \\
1.84 \\
0.18^{\mathrm{a}}\end{array}$ & $\begin{array}{l}0.04 \\
0.01 \\
0.03\end{array}$ & $\begin{array}{l}0.03 \\
0.03 \\
0.01^{\mathrm{a}}\end{array}$ & $\begin{array}{l}0.02 \\
0.42 \\
0.03\end{array}$ \\
\hline Proximal droplet & $\begin{array}{c}\text { I } \\
\text { II } \\
\text { III }\end{array}$ & $\begin{array}{l}8.46^{\mathrm{b}} \\
3.58^{\mathrm{A}} \\
3.42^{\mathrm{A}}\end{array}$ & $\begin{array}{l}9.30^{\mathrm{a}} \\
7.69^{\mathrm{ABC}} \\
9.84^{\mathrm{ABC}}\end{array}$ & $\begin{array}{l}7.40^{\mathrm{C}} \\
3.44^{\mathrm{B}} \\
3.50^{\mathrm{B}}\end{array}$ & $\begin{array}{l}2.52^{\mathrm{abc}} \\
2.57^{\mathrm{C}} \\
2.60^{\mathrm{C}}\end{array}$ & $\begin{array}{l}0.57 \\
0.55 \\
0.73\end{array}$ \\
\hline Dags defect & $\begin{array}{c}\text { I } \\
\text { II } \\
\text { III }\end{array}$ & $\begin{array}{l}0.44 \\
0.48^{\mathrm{b}} \\
0.38\end{array}$ & $\begin{array}{l}0.15^{\mathrm{a}} \\
0.45^{\mathrm{a}} \\
0.58\end{array}$ & $\begin{array}{l}0.50^{\mathrm{a}} \\
0.16^{\mathrm{ab}} \\
0.28\end{array}$ & $\begin{array}{l}0.22 \\
0.27 \\
0.43\end{array}$ & $\begin{array}{l}0.06 \\
0.05 \\
0.06\end{array}$ \\
\hline Other major defects & $\begin{array}{c}\text { I } \\
\text { II } \\
\text { III }\end{array}$ & $\begin{array}{l}0.26 \\
0.13 \\
0.15\end{array}$ & $\begin{array}{l}0.17 \\
0.37 \\
0.41\end{array}$ & $\begin{array}{l}0.18 \\
0.13 \\
0.23\end{array}$ & $\begin{array}{l}0.17 \\
0.23 \\
0.48\end{array}$ & $\begin{array}{l}0.04 \\
0.08 \\
0.08\end{array}$ \\
\hline \multicolumn{7}{|c|}{ Minor defects, \% } \\
\hline Free normal head & $\begin{array}{c}\text { I } \\
\text { II } \\
\text { III }\end{array}$ & $\begin{array}{l}0.96 \\
0.52 \\
0.19\end{array}$ & $\begin{array}{l}0.67 \\
0.29 \\
0.23\end{array}$ & $\begin{array}{l}0.25 \\
0.43 \\
0.28\end{array}$ & $\begin{array}{l}0.23 \\
0.40 \\
0.43\end{array}$ & $\begin{array}{l}0.16 \\
0.06 \\
0.06\end{array}$ \\
\hline Abaxial implantation & $\begin{array}{c}\text { I } \\
\text { II } \\
\text { III }\end{array}$ & $\begin{array}{l}1.72 \\
2.04 \\
1.06\end{array}$ & $\begin{array}{l}2.27^{\mathrm{A}} \\
2.81^{\mathrm{A}} \\
2.47^{\mathrm{a}}\end{array}$ & $\begin{array}{l}2.13^{b} \\
1.66 \\
1.93\end{array}$ & $\begin{array}{l}0.65^{\mathrm{Ab}} \\
0.80^{\mathrm{A}} \\
0.88^{\mathrm{a}}\end{array}$ & $\begin{array}{l}0.22 \\
0.32 \\
0.26\end{array}$ \\
\hline Distal droplet & $\begin{array}{c}\text { I } \\
\text { II } \\
\text { III }\end{array}$ & $\begin{array}{l}3.52^{\mathrm{ab}} \\
1.96^{\mathrm{A}} \\
2.67^{\mathrm{c}}\end{array}$ & $\begin{array}{l}4.85^{\mathrm{AB}} \\
5.10^{\mathrm{ABC}} \\
5.23^{\mathrm{ABC}}\end{array}$ & $\begin{array}{l}2.02^{\mathrm{Aa}} \\
1.96{ }^{\mathrm{AB}} \\
1.78^{\mathrm{A}}\end{array}$ & $\begin{array}{l}1.75^{\mathrm{Bb}} \\
2.25^{\mathrm{C}} \\
2.08^{\mathrm{B}}\end{array}$ & $\begin{array}{l}0.32 \\
0.41 \\
0.40\end{array}$ \\
\hline Simple bent tail & $\begin{array}{c}\text { I } \\
\text { II } \\
\text { III }\end{array}$ & $\begin{array}{l}0.85^{\mathrm{a}} \\
1.06^{\mathrm{a}} \\
0.85^{\mathrm{a}}\end{array}$ & $\begin{array}{l}1.40 \\
0.79 \\
2.53^{\text {a }}\end{array}$ & $\begin{array}{l}2.56^{\mathrm{a}} \\
1.20 \\
1.20\end{array}$ & $\begin{array}{l}1.70 \\
0.85 \\
1.48\end{array}$ & $\begin{array}{l}0.32 \\
0.16 \\
0.29\end{array}$ \\
\hline Other minor defects & $\begin{array}{c}\text { I } \\
\text { II } \\
\text { III }\end{array}$ & $\begin{array}{l}0.11 \\
0.17 \\
0.38\end{array}$ & $\begin{array}{l}0.23 \\
0.24 \\
0.19\end{array}$ & $\begin{array}{l}0.26 \\
0.11 \\
0.29\end{array}$ & $\begin{array}{l}0.28 \\
0.20 \\
0.17\end{array}$ & $\begin{array}{l}0.05 \\
0.03 \\
0.05\end{array}$ \\
\hline
\end{tabular}

SEM - standard error of means

$A, B, C, D-$ means in rows with the same letters are significantly different at $P \geq 0.01$

a,b,c,d - means in rows with the same letters are significantly different at $\mathrm{P} \geq 0.05$ 
Among the other forms of minor changes, the spermatozoa with distal droplet were the most numerous. We did not detect a decrease of minor defects with the following evaluations. The highest number of spermatozoa with distal droplet was detected in Pietrain boars semen and Duroc, and the lowest number in hybrids of those groups. The differences were statistically significant at $\mathrm{P} \leq 0.01$ and $\mathrm{P} \leq 0.05$.

In this study we assessed the phenotypic correlation coefficient between the traits of semen of the examined boars. The results shown in Tab. 3 illustrate that there was significant $(\mathrm{P} \leq 0.01)$ correlation between the percentage of spermatozoa with major defects and other traits of semen.

Table 3

Coefficients of phenotypic correlation between tested traits of semen (Phänotypische Korrelationen zwischen geprüften Merkmale von Ebersperma)

\begin{tabular}{|c|c|c|c|c|c|c|c|}
\hline Traits semen & $\begin{array}{l}\text { Ejaculate } \\
\text { volume }\end{array}$ & $\begin{array}{l}\text { Motile } \\
\text { spermato- } \\
\text { zoa }\end{array}$ & $\begin{array}{l}\text { Concentra- } \\
\text { tion of } \\
\text { spermato- } \\
\text { zoa }\end{array}$ & $\begin{array}{c}\text { Total } \\
\text { number of } \\
\text { spermato- } \\
\text { zoa }\end{array}$ & $\begin{array}{l}\text { Spermato- } \\
\text { zoa with } \\
\text { normal } \\
\text { acrosome }\end{array}$ & Test ORT & AspAT \\
\hline $\begin{array}{l}\text { Spermatozoa } \\
\text { with major } \\
\text { defects, \% }\end{array}$ & $-0.169 * *$ & $-0.365^{* *}$ & $-0.297 * *$ & $-0.320 * *$ & $-0.337 * *$ & $-0.155^{*}$ & $0.389 * *$ \\
\hline $\begin{array}{l}\text { Spermatozoa } \\
\text { with minor } \\
\text { defects, \% }\end{array}$ & -0.088 & $-0.295^{* *}$ & $-0.147 * *$ & $-0.189 * *$ & $-0.214^{* *}$ & $-0.184^{* *}$ & $0.277^{* *}$ \\
\hline $\begin{array}{l}\text { Normal } \\
\text { spermatozoa, } \\
\%\end{array}$ & $0.158 * *$ & $0.402 * *$ & $0.281 * *$ & $0.337 * *$ & $0.344^{* *}$ & $0.199 * *$ & $0.407 * *$ \\
\hline $\begin{array}{l}\text { Spermatozoa } \\
\text { with normal } \\
\text { acrosome, \% }\end{array}$ & 0.040 & $0.146^{* *}$ & 0.070 & $0.107^{*}$ & - & $0.646 * *$ & $0.157 * *$ \\
\hline Test ORT & -0.100 & 0.066 & 0.001 & -0.046 & $0.646^{* *}$ & - & 0.012 \\
\hline AspAT & -0.003 & $-0.293 * *$ & $-0.354 * *$ & $-0.247 * *$ & $-0.157 * *$ & 0.012 & - \\
\hline
\end{tabular}

Significantly lower correlation coefficients, although statistically significant, were assessed for those traits of semen and percentage of spermatozoa with minor defects. The results indicate that the increase of percentage of morphologically changed spermatozoa, especially concerning major defects is connected to the lower quality of semen. The other correlation coefficients from Tab. 3 show (statistically significant with $\mathrm{P} \leq 0.01$ and $\mathrm{P} \leq 0.05$ ) clearly that the evaluation of acrosome of spermatozoa, as well as the analysis of activity of AspAT in semen plasma and ORT test have significant importance in the final evaluation of semen. We would like to emphasize that the highest correlation coefficients was assessed for percentage of spermatozoa with normal acrosome (after collection in semen) and value of ORT test.

Table 4 shows the correlation coefficients between particular forms of morphologically changed spermatozoa in boars' semen and other traits of ejaculate. Among the main anomalies of spermatozoa, the highest number of significant correlations $(\mathrm{P} \leq 0.01)$ was detected for proximal droplet spermatozoa, pear shaped heads, narrow at the base spermatozoa, small, abnormal head spermatozoa and many other traits of semen. It is worth emphasizing that the highest correlation coefficients 
were detected between spermatozoa with proximal droplet and all of the traits of semen under investigation. There were significantly less correlations between minor defect spermatozoa and traits of the boars' semen. It is worth noting, that the highest, significant positive correlation were assessed between the activity of AspAT in semen plasma and different forms of abnormal spermatozoa and negative correlation between the mobility of spermatozoa and different defects of spermatozoa.

Table 4

Coefficients of phenotypic correlation between tested traits of semen and each defects of spermatozoa (Phänotypische Korrelationen zwischen geprüften Merkmalen von Ebersperma und verschiedenen Spermienanomalien bei Ebern

\begin{tabular}{|c|c|c|c|c|c|c|c|}
\hline $\begin{array}{l}\text { Traits } \\
\text { semen }\end{array}$ & $\begin{array}{l}\text { Ejaculate } \\
\text { volume }\end{array}$ & $\begin{array}{l}\text { Motile } \\
\text { Spermato- } \\
\text { zoa }\end{array}$ & $\begin{array}{l}\text { Concentra- } \\
\text { tion of } \\
\text { spermato- } \\
\text { zoa }\end{array}$ & $\begin{array}{c}\text { Total } \\
\text { number } \\
\text { of } \\
\text { spermato- } \\
\text { zoa }\end{array}$ & $\begin{array}{c}\text { Spermato- } \\
\text { zoa } \\
\text { with } \\
\text { normal } \\
\text { acrosome }\end{array}$ & Test ORT & AspAT \\
\hline $\begin{array}{l}\text { Double } \\
\text { forms }\end{array}$ & 0.048 & -0.074 & $-0.131^{* *}$ & -0.063 & -0.069 & -0.106 & 0.050 \\
\hline $\begin{array}{l}\text { Pear shaped } \\
\text { head }\end{array}$ & $-0.101 *$ & $-0.182 * *$ & $-0.165^{* *}$ & $-0.203^{* *}$ & $-0.193 * *$ & -0.058 & $0.157 * *$ \\
\hline $\begin{array}{l}\text { Narrow at } \\
\text { the base }\end{array}$ & $-0.129 *$ & $-0.241^{* *}$ & $-0.147 * *$ & $-0.185 * *$ & $0.228 * *$ & $-0.135^{*}$ & $0.170 * *$ \\
\hline $\begin{array}{l}\text { Small } \\
\text { abnormal } \\
\text { head }\end{array}$ & -0.062 & $-0.252^{* *}$ & -0.091 & $-0.101 *$ & $-0.134^{* *}$ & $-0.132 *$ & $0.443^{* *}$ \\
\hline $\begin{array}{l}\text { Proximal } \\
\text { droplet }\end{array}$ & $-0.144 * *$ & $-0.275^{* *}$ & $-0.276 * *$ & $-0.325 * *$ & $-0.273 * *$ & $-0.133^{*}$ & $0.258 * *$ \\
\hline Dag defect & -0.066 & $-0.213^{* *}$ & -0.096 & -0.086 & $-0.146^{* *}$ & -0.064 & $0.218 * *$ \\
\hline $\begin{array}{l}\text { Other major } \\
\text { defects }\end{array}$ & -0.079 & $-0.185^{* *}$ & -0.065 & $-0.107 *$ & $-0.154 * *$ & 0.004 & $0.287^{* *}$ \\
\hline $\begin{array}{l}\text { Free normal } \\
\text { head }\end{array}$ & -0.036 & -0.053 & -0.096 & -0.093 & -0.027 & -0.042 & $0.151 * *$ \\
\hline $\begin{array}{l}\text { Abaxial } \\
\text { implantation }\end{array}$ & -0.048 & -0.081 & -0.096 & $-0.129 * *$ & -0.040 & 0.013 & $0.130 * *$ \\
\hline $\begin{array}{l}\text { Distal } \\
\text { droplet }\end{array}$ & -0.035 & $-0.188^{* *}$ & -0.045 & -0.076 & $-0.159 * *$ & $-0.223 * *$ & $0.172 * *$ \\
\hline $\begin{array}{l}\text { Simple bent } \\
\text { tail }\end{array}$ & -0.075 & $-0.274 * *$ & $-0.136^{* *}$ & $-0.147 * *$ & $-0.177 * *$ & -0.049 & $0.161 * *$ \\
\hline $\begin{array}{l}\text { Other minor } \\
\text { defects }\end{array}$ & -0.014 & -0.023 & 0.057 & 0.048 & -0.023 & -0.104 & 0.054 \\
\hline
\end{tabular}

\section{Discussion}

Insemination of sows can be beneficiary as well from a breeding and economic point of view. The only condition is a suitable selection of boars having good quality semen. The right movement of spermatozoa is a good indicator of vitality and fertility of boar. The results of studies carried out by STRZEŻEK (1998) show that there is a positive correlation between the mobility of spermatozoa and level of spermatozoa penetration, conception rate and number of piglets born alive in a litter. We can expect that for the 
boars having ejaculate with higher percentage of spermatozoa with normal movement ( $70 \%$ and above), we will have high sow fertility rates. In the present study the average of spermatozoa motility amounted more than $70 \%$ for all groups of animals. This value is required for semen of young boars designed to insemination (PAWLAK et al., 1998). However, Pietrain boars had semen with the worst mobility of spermatozoa during the following evaluation in the $230^{\text {th }}, 250^{\text {th }}$ and $270^{\text {th }}$ day of life. The highest mobility of spermatozoa was characteristic for semen of hybrid boars resulting from mating of Duroc fathers and Pietrain mothers. Ejaculates of those hybrids had also the highest concentration of spermatozoa, higher even than the concentration of spermatozoa of Duroc boars' semen. It is commonly known, that the reproducers of Duroc usually have ejaculates, with extremely high concentration of spermatozoa (KOĆWIN-PODSIADŁA et al., 1990; KONDRACKI et al., 2003).

The total number of spermatozoa in ejaculate is determining the number of insemination doses, which can be made from one ejaculate (KONDRACKI et al., 2003). In the present study the highest number of spermatozoa per ejaculate was obtained from Duroc boars (especially during evaluation in the $270^{\text {th }}$ day of life). These results are slightly different from the results of other studies (KOĆWINPODSIADŁA et al., 1990; KONDRACKI et al., 2003). The authors show that Duroc boars had the lowest ejaculate volume and total number of spermatozoa, comparing to boars of different breeds and their hybrids. In the present study the total number of spermatozoa in ejaculate of hybrid boars (both groups) was insignificantly higher in comparison to ejaculates of Pietrain boars. In many studies the significant higher number of spermatozoa in ejaculates of hybrid boars in compare to boars of parental breeds has been proved (NELLY et al., 1980; FENT et al., 1983; KONDRACKI et al., 2003). Among many traits of semen, the percentage of normal spermatozoa is related to the results of boar fertility. The heritability coefficient of the percentage of normal spermatozoa determined in many studies shows the possibility of carrying out a selection on the basis of this trait. It was found that there was a positive correlation between the percentage of normal spermatozoa in semen and number of piglets born in litters (FALKENBERG et al., 1982; 1984; 1991; 1994).

In boar semen with normal fertility the appearance of some percentage of spermatozoa with morphological changes is permitted. However, there are different opinions on the amount of that spermatozoa and the type of changes. According to BONET et al., (1992) the percentage of spermatozoa with morphological changes in boar ejaculates should not exceed $1-2 \%$. The appearance of a change in spermatozoa in the amount of $20 \%$ or more disqualifies the semen. In Polish artificial insemination stations it is assumed that having more than $15 \%$ of major changes in semen (during the following evaluation) qualifies the boar for removal from the herd (PAWLAK et al., 1998).

In the present study, the highest percentage of major defects of spermatozoa was noted during the first evaluation ( $230^{\text {th }}$ day of life) of the semen of Pietrain boars, Duroc boars and hybrids of Pietrain fathers and Duroc mothers. On the other hand, the hybrids of opposite combination (Duroc fathers and Pietrain mothers) had a low percentage of those changes. During the following evaluations the number of major defects decreased in all of the boars except Pietrain.

During the analysis of the forms of spermatozoa, concerning the major defects, it was noted that the spermatozoa with proximal droplet are the most common defective spermatozoa in the semen of young boars. The appearance of this change is considered 
to be an indicator of the immaturity of spermatozoa (STRZEŻEK, 1996). FALKENBERG et al., (1988) indicated that among other morphological changes, spermatozoa with proximal droplet have the highest heritability coefficient $\left(\mathrm{h}^{2}=0.28\right)$ as does the sum of all of the anomalies of spermatozoa of semen $\left(h^{2}=0.26\right)$, which, according to the author, is the basis to consider these traits as an important indicator in the general evaluation of semen, also useful for selection.

In the present study, the highest percentage of spermatozoa with proximal droplet was observed in the semen of Pietrain boars. This form of abnormal spermatozoa clearly decreased during the following evaluations in all of the groups except this one. It is worth emphasizing that the lowest percentage of spermatozoa with this defect was observed in hybrid boars resulting from the mating of Duroc fathers and Pietrain mothers even during the first evaluation. The other major changes appeared in most of the cases at less than $1 \%$.

The minor defects of spermatozoa are defined by BLOM (1981), as having minor import for the fertility of a boar. According to the author, only the solitary changes of spermatozoa exceeding 10-15\%, should be considered in a final assessment. According to WABERSKI et al., (1994), the presence of distal droplets in semen should be considered as a significant failure of spermatozoa. It is caused by negative correlations of the fertility of pigs.

Among minor defects observed in the semen of the examined boars, the most numerous were: spermatozoa with distal droplet, abaxial implantation spermatozoa, and simple bent tail spermatozoa. Spermatozoa with distal droplet and abaxial implantation spermatozoa were the most common semen of Pietrain boars during the following examinations.

Other studies (KONDRACKI and WYSOKIŃSKA, 2005; UDAŁA et al., 2005; WABERSKI, et al. 1994) showed, that spermatozoa with proximal droplet are the most common major defect of boar semen. Among the minor defects, the most common were distal droplet spermatozoa and simple bent tail spermatozoa.

In order to receive more detailed examination of semen, we carried out the analysis of acrosome morphology, osmotic resistance test of acrosomal membranes (ORT) and also the activity of (AspAT) is semen plasma. Morphology of acrosome is an extremely important criteria of spermatozoa evaluation, because of the localization of enzymes that take part in the process of fertilization of an egg cell, in this structure (STRZEŻEK, 1996). Therefore all of the disorders of acrosome structure, disturbances of membrane function or its damage, can decrease the chance of spermatozoa taking part in fertilization.

The results of acrosome morphology examination are analogous to results concerning major and minor defects of spermatozoa. The semen of Pietrain boars had also the lowest number of normal spermatozoa (from $80.13 \%$ during the first assessment to $77.13 \%$ during the third semen assessment). This number did not increase with age (from the $230^{\text {th }}$ to the $270^{\text {th }}$ day of life), as in boars of other groups, where the decrease of percentage of major defects of spermatozoa in semen was most visible. It may be possible that Pietrain boars reach the ability of producing semen of better quality as they get much older. However, KONDRACKI et al., (2003), comparing morphology of spermatozoa of semen in stationary boars of Pietrain, Duroc and their hybrids, also observed the appearance of the lowest number of normal spermatozoa in the semen of Pietrain boars (85.24\%). These authors also reveled that boar semen that breed has the 
highest percentage of boars with major defects and quite a high number of spermatozoa with minor defects. The worse quality of semen of Pietrain boars probably results with charged of the breed by $R Y R 1^{\mathrm{T}}$ gene $(\mathrm{GREGOR}$ and HARDGE, 1995).

For the last few years, the test of osmotic resistance ORT has been used in order to evaluate the quality of semen and predict its fertilization abilities (SCHILING and VENGUST, 1987; STRZEŻEK et al., 1992; UDAŁA et al., 1996). This test differs spermatozoa according to the functional condition of cell membrane. Incubation of fresh samples of semen in different osmolalities influences the condition of acrosome, causing a decrease in the percentage of spermatozoa with normal acrosome. It proves the reduction of osmotic resistance of acrosomal membranes, and the decrease of semen quality (SCHILING and VENGUST, 1987). According to SCHILING and VENGUST (1987) and STRZEŻEK et al., (1992), mean values of ORT for the fresh semen vary from 62 to $70 \%$. In our studies, the highest value of ORT was in the semen of hybrid boars descending from the crossing of Duroc fathers and Pietrain mothers.

The measuring of AspAT activity in semen plasma is a test which allows the evaluation of possible changes of the permeability of cell membrane of spermatozoa (STRZEŻEK et al., 1996). A "leak" of that enzyme into the semen plasma proves the decrease of biological value of the spermatozoa, which consequently can have negative influence on the number of fertilized egg cells and the survival of embryos (BRONICKA and DEMBIŃSKI, 1999). In this study the lowest AspAT level had semen plasma of hybrid boars resulting from mating of Duroc fathers and Pietrain mothers. Its activity in plasma clearly decreased during the following evaluations of ejaculates of all of the groups, except Pietrain boars.

Coefficients of phenotypic correlation indicate the existence of a significant correlation between spermatozoa and morphological changes, especially major defects, and many traits of the semen, i.e.: volume of ejaculate, percentage of spermatozoa with normal motile, concentration of spermatozoa, total number of spermatozoa in ejaculate, percentage of spermatozoa with normal acrosome, test of osmotic resistance of acrosomal membranes of spermatozoa (ORT), and activity of AspAT in semen plasma. It indicates the necessity of monitoring the morphological changes of semen, as they are an indicator of testes efficiency.

To sum up, we have to affirm, that among all four of examined groups, i.e.: Pietrain boars, Duroc boars and their hybrids resulting from reciprocal crossing, Pietrain boars had ejaculates with the lowest volume, the lowest mobility of spermatozoa, and least total number of spermatozoa in semen. Semen of those boars also had the highest percentage of spermatozoa with morphological changes - major and minor - and defective acrosome. Along with the age of boars (from $230^{\text {th }}$ to $270^{\text {th }}$ day of life) there was a clear improvement of semen traits detected in all of the groups, except the semen of Pietrain boars.

Among major anomalies of spermatozoa, the most common ones are spermatozoa with protoplasmatic, proximal droplet. The most common minor defects are spermatozoa with distal droplet and abaxial implantation spermatozoa.

The breed crossing effect revealed especially in hybrid boars descending from the mating of Duroc fathers and Pietrain mothers. Even during the first assessment semen of that group had the highest number of normal spermatozoa and spermatozoa with normal acrosome, and also the highest value of osmotic resistance test of spermatozoa 
and the lowest activity of AspAT in semen plasma. It indicates the high quality of ejaculates collected from those hybrids compared to the ejaculates of boars of other groups, as well purebreds and opposite combinations, i.e. descending from the crossing of Pietrain fathers and Duroc mothers. It suggests the use of the Duroc breed as a father component and Pietrain breed as mother for the production of hybrid boars.

BLOM, E.:

\section{References}

Studies on seminal vesiculitis in the bull: II. Proposal for a new classification of the spermiogram. Medycyna Wet., Lublin, Poland, 37 (1981) 4, 239-242

BONET, S.; BRIZ, M.; FRADERA, A.; EGOZCUE, J.:

Origin, development and ultrastructure of boar spermatozoa with folded tails and two tails. Human Reprod., 7 (1992), 523-528

BRONICKA, A.; DEMBINSKI, Z.:

Current criteria and conditions influencing the quality of boar semen. Medycyna Wet., Lublin, Poland, 55, 7 (1999), 436-439

DZIADEK, K.:

Reproductive usefulness of Duroc and line 990 boars depending of the characteristics of the litter in which they were born and on their own fattening and slaughter performance. Ann. Anim. Sci. IZ Kraków, Poland, Habilitation Thesis 10 (1999)

FALKENBERG, H.; RITTER, E.; ABSHAGEN, H.: Untersuchung genetischer Aspekte an Spermamerkmalen von Jungebern. Arch. Tierz., Berlin 25 (1982) 2, 95-107

FALKENBERG, H.; RITTER, E.; STIENHANS H.:

Zur züchterischen Bewertung der Beziehungen zwischen Spermaqualität und Fruchtbarkeitsleistung von Ebern. Arch. Tierz., Berlin 27 (1984) 6, 523-534

FALKENBERG, H.; HAMMER, H.; RITTER, E.; ABSHAGEN, H.:

Untersuchungen zur genetischen Determination der Besamungstauglichkeit von Jungebern. 1. Mitt.: Untersuchungen an Spermamerkmalen. Arch. Tierz., Berlin 31 (1988) 5, 489-499

FALKENBERG, H.; HAMMER, H.; RITTER, E.:

Genetische und phänotypische Beziehungen zwischen Merkmalen der Mast- und Ansatzleistung von Ebern in zentralen Aufzuchtstationen, der Besamungseignung dieser Tiere sowie der Wurfleistung ihrer Schwestern. Arch. Tierz., Berlin 32 (1989) 2, 163-171

FALKENBERG, H.; RITTER, E.; HAMMER, H.:

Bewertung des genetischen Einflusses bei Sperma-, Verhaltens- und Hodenmerkmalen von Jungebern sowie deren Beziehungen zu Mast- und Schlachtleistungen. Arch. Tierz., Dummerstorf 34 (1991) 4, 303-311

FALKENBERG, H.; RITTER, E.:

Beziehungen zwischen morphologischen sowie biochemischen Spermamerkmalen bei Ebern und Wurfleistungen von Sauen. Arch. Tierz., Dummerstorf 37 (1994) 3, 287-300

FENT, R.W.; WETTEMANN, R.P.; JOHNSON, R.K.:

Breed and heterosis effects on testicular development and endocrine function of pubertal boars. J. Anim. Sci. 57 (1983), 425-432

GREGOR, G.; HARDGE, T.:

Zum Einfluss von Ryanodin-Rezeptor-Genvarianten auf Spermaqualitätsmerkmale bei KB-Ebern. Arch. Tierz., Dummerstorf 38 (1995) 5, 527-538

KAWĘCKA, M.; CZARNECKI, R.; OWSIANNY, J.; RÓŻYCKI, M.; DZIADEK, K.:

Relationship between performance tested traits of young boars of line 990 and their reproduction usefulness. Ann. Anim. Sci., Kraków, Poland, 24, 4 (1997), 89-101

KOĆWIN-PODSIADŁA, M.; POLAŃSKA, E.; DZIADEK, K.:

Basic and biochemical traits of the semen of young boars of Polish Large White and Duroc breed and polybred hybrids. Zesz. Probl. Post. Nauk Rol., Warszawa, Poland, 384 (1990), 63-70

KONDRACKI, S.; WYSOKIŃSKA, A.; KOWALCZYK, Z.:

The effect of crossing of Duroc and Pietrain breeds on semen quality of crossbred boars. Anim. Prod. Rev., App. Sci. Rep., Pig Production and Breeding., Warszawa, Poland, 68, 2 (2003), 105-111

KONDRACKI, S.; WYSOKIŃSKA, A.:

Characterization of sperm abnormalites of boars with regard of age and breed. Folia Univ. Agric. Stetin., Zoot. 243, 47 (2005), 96-103 
MORSTIN, J.:

Defects of spermatozoa of male animal breeding and their relation with fertility. [in: Andrology in fertility of pigs] Symposium to dedication Prof. S. Wierzbowski. IZ Kraków, Poland (1996), 58-64

NEELY, J.D.; JOHNSON, B.H.; ROBISON, O.W.:

Heterosis estimates for measures of reproductive traits of crossbred boars. J. Anim. Sci. 51 (1980), 1070-1077

NELLY, J.D.; ROBISON, O.W.:

Estimates of heterosis for sexual activity in boars. J. Anim. Sci., 56 (1983): 1150-1157

PAWLAK, H.; GASIŃSKI, M.; PEJSAK, Z.; TARASIUK, K.:

Reproductive performance of boars in station of insemination sows. CSHZ Warszawa, Poland (1998)

SAACKE, R.G.; WHITE, J.M.:

Semen quality tests and their relationship to fertility. [in: Proceedings $4^{\text {th }}$ Technical Conference Animal Production and Artificial Insemination 1972] 2

SCHILLING, E.; VENGUST, M.:

Frequency of semen collection in boars and quality of ejaculates as evaluated by the osmotic resistance

STRZEŻEK, J.: of acrosomal membrane. Anim. Repr. Sci. 12 (1987), 283-290

The semen and reproductive performance of boar [in: Andrology Red. S. Wierzbowski. Platan, Kryspinów, Kraków, Poland (1996), 201-246

STRZEŻEK, J.:

The current of problems insemination of sows - factors to have influenced for its effectiveness. Anim. Prod. Rev., App. Sci. Rep., Pig Production and Breeding. Warszawa, Poland, 39 (1998), $49-73$

STRZEŻEK, J.; DEMIANOWICZ, W.; NOGALSKI, G.; ZALECIŁO, A.:

The application of osmotic resistance test (ORT) for control of boar semen quality. [in: Materials of $9^{\text {th }}$ Congress PTNW., II]. ART Olsztyn, Poland (1992): 472

UDAŁA, J.; KRASNOSIELSKA-WARCHOŁ, D.; ROZEN, J.; RADOŃ, W.:

The usefulness of osmotic resistance test (ORT) for evaluation of the fertilizing capability of boar semen. Anim. Prod. Rev., App. Sci. Rep., Pig Production and Breeding. Warszawa, Poland, 26 (1996), 83- 90

UDAŁA, J.; GĄCZARZEWICZ, D.; LASOTA, B.; BŁASZCZYK, B:

Characteristics of the morphological defects of boars spermatozoa used in artificial insemination. Folia Univ. Agric. Stetin., Zoot. 243, 47 (2005), 160-172

WABERSKI, D.; MEDING, S.; DIRKSAEN, G.; WEITZE, K.F.; LEWIDING, C.; HAHN, R.: Fertility of long term-stored boar semen: influence of extender (Androhep and Kiev), storage time and plasma droplets in the semen. Anim. Reprod. Sci. 36 (1994), 145-151

WILSON, E.R.; JOHANSON, R.K.; WETTEMAN, R.P.:

Reproductive and testicular characteristics of purebred and crossbred boars. J. Anim. Sci. 66 (1977), 3742

Received: 2006-05-22

Accepted: 2007-08-17

Author's address

MARIA KAWĘCKA*, PhD DSc, Prof.; ARKADIUSZ PIETRUSZKA, PhD; Prof. EUGENIA

JACYNO, PhD DSc; Prof. ROMAN CZARNECKI, PhD DSc; MARIAN KAMYCZEK, PhD

Departement of Pig Breeding, University of Agriculture, Dr Judyma 10 st.,

71-460 SZCZECIN, POLAND

*Corresponding author, E-Mail: Maria.Kawecka@biot.ar.szczecin.pl 